\title{
Questions on the Book of Job
}

\author{
Warren Zev Harvey \\ Department of Jewish Thought, The Hebrew University of Jerusalem, Jerusalem 91905, Israel \\ Email: zeev.harvey@mail.huji.ac.il
}

(Received 14 September 2021; revised 26 December 2021; accepted 27 December 2021)

\begin{abstract}
The Book of Job treats of the Problem of Evil. It is divided into two documents: (1) the framework story, that is, the Prologue and the Epilogue (Job 1:1-2:13; 42:7-17); and (2) the speeches by Job, his friends, and God. In the framework story, Job is presented as a just man who serves God in good times and bad (Job 1:21; 2:10). In the speeches, God is accused by Job of 'destroying the hope of man' (Job 14:19). God replies with an ad hominem argument: 'Where were you when I laid the foundation of the earth?' (Job 38:4). If God argues that it is unfair for humans to judge God, Job argues that it is unfair for God to judge humans.
\end{abstract}

Keywords: Compassion; evil; hope; Job; love; Satan; suffering

The Book of Job is part of the Hagiographa division of the Hebrew Bible, and is considered to belong to the Hebrew Wisdom Literature, together with books like Proverbs, Ecclesiastes, and Ecclesiasticus. ${ }^{1}$ It is an ancient book, which seems to have been written about the sixth or fifth century BCE, that is, in the beginning of the Second Temple Period. The book treats of the Problem of Evil. It is the main biblical discussion of the problem and one of its classical discussions in world literature. Why do the innocent suffer? Why do the righteous suffer? Why is there evil in the world? Why does God allow evil?

From a literary point of view, the book is clearly divided into two different documents: (1) The framework story, that is, the Prologue and the Epilogue (Job 1:1-2:13; 42:7-17), written in prose; (2) and the body of the book, consisting of speeches by Job, his friends, and God, which treat of the Problem of Evil, and are written in poetic form. The language of the framework story is simple and ingenuous. The language of the speeches is rich, complex, and ornate. The philosopher Robert Sacks, in his book on Job, says that moving from the Prologue to the body of the text is 'like turning from Dick and Jane to Shakespeare'. ${ }^{2}$

The difficult and often enigmatic nature of the Hebrew of the speeches led Rabbi Abraham ibn Ezra (c. 1093-c. 1167), in his Commentary on Job, to speculate that the book was not written originally in Hebrew, but translated into Hebrew from another language. ${ }^{3}$ Ibn Ezra's view was cited approvingly by Spinoza in his Theologico-Political Tractatus, chapters 7 and 10. ${ }^{4}$ Some modern scholars have agreed with Ibn Ezra, and have argued that the book was originally written in Aramaic, Arabic, or Canaanite. ${ }^{5}$

The framework story gives us information about Job and the evils that befell him, and tells of a curious wager made between God and Satan. The poetic speeches, which constitute the body of the book, all concern the Problem of Evil and the human condition, and

(c) The Author(s), 2022. Published by Cambridge University Press. This is an Open Access article, distributed under the terms of the Creative Commons Attribution licence (http://creativecommons.org/licenses/by/4.0/), which permits unrestricted re-use, distribution and reproduction, provided the original article is properly cited. 
are spoken by Job, his friends, and God. His friends are initially three elders: Eliphaz the Temanite, Bildad the Shuhite, and Zophar the Naamathite. They are joined by a young man, Elihu the son of Barachel the Buzite, who speaks in chapters 32-37. These friends, who have come to comfort Job (Job 2:11), voice various opinions about the Problem of Evil. They generally agree that evils that happen to human beings are a divine punishment for sins, and thus, if evils have befallen Job, he must have sinned, whether or not he is aware of having done so (e.g. Job 4:7).

Do Job's friends represent different philosophical or theological schools? Many medieval philosophers were inclined to think so. Maimonides (1138-1204), in his Guide of the Perplexed, Part III, chapters 22-23, held that Job voices the opinion of Aristotle that there is no divine providence on earth; Eliphaz voices the opinion of the Law that all punishment is deserved; Bildad voices the opinion of the Mu'tazila that suffering is for the sake of reward; and Zophar voices the opinion of the Ash ariyya that everything is due to God's inscrutable Will. As for Elihu, he may be understood as voicing Maimonides' own opinion that Providence means human knowledge or wisdom. ${ }^{6}$

The speeches of Eliphaz, Bildad, and Zophar enunciate a traditionalist theology, and serve as a foil for the radical speeches of God and Job, which constitute the heart of the book. The Elihu chapters seem to be a later interpolation, but the reason for the interpolation is unclear. It has been debated whether Elihu sides with the traditionalism of the three elderly friends or with the radicalism of God and Job. ${ }^{7}$ Maimonides asserts that Elihu exoterically agrees with the three elders, but esoterically disagrees with them. ${ }^{8}$ My comments in what follows will focus on the confrontation between Job and God.

\section{The Framework Story (Job I:I-2:I3; 42:7-I7)}

I would like to ask one question about the framework story, that is, the Prologue and the Epilogue. Is it in any way necessary for the plot? Is it in any way helpful for the plot? Does it help us understand the book? Does it contribute to the development of the theme which concerns the Problem of Evil? In my view, the framework story trivializes the theme and undermines it.

The speeches in the body of book attributed to God, Job, Eliphaz, Bildad, Zophar, and Elihu treat of the Problem of Evil in a most profound way, and raise the question of why the innocent suffer. The framework story gives an outrageous answer to this question: The innocent suffer because God makes bets with Satan - imprudent and ill-conceived bets. God Himself admits that His bet with Satan was wrong and rash, and his abuse of Job was not justified. He complains to Satan: 'you incited Me against him [va-tesiteni bo], to destroy him without cause [hinnam]' (Job 2:3). You incited Me against him! Satan is often conceived as the one who incites human beings to do bad things, but here he is presented in God's ipsissima verba as the one who incites God to do bad things!

The word satan in the Hebrew Bible usually refers to an accuser or adversary, either earthly or heavenly (e.g. Numbers 22:22; Zechariah 3:1-2; Psalms 109:6). Here Satan is some kind of angelic being, one of the 'sons of God' (Job 1:6-7; cf. 38:7), although evidently one with a special status.

What happens in the framework story?

We are told three times that Job is 'blameless, upright, God-fearing, and shunning evil' (Job 1:1, 8; 2:3). Maimonides, however, emphasizes that it does not say Job was wise or intelligent. ${ }^{9}$ Job was also exceedingly wealthy, and 'the greatest man in the East' (Job 1:3).

When God boasts to Satan about his excellent servant Job, Satan replies that Job is pious only because God has made his life easy, giving him all kinds of material blessings. Take them away, argues Satan, and Job will become a blasphemer (Job 1:8-11). God, in response, permits Satan to try Job. Satan thereupon destroys his possessions and wealth, 
murders his seven sons and three daughters, and afflicts him with painful boils (Job 1:1219; 2:4-8). However, Job refuses to blaspheme God (Job 1:20-22; 2:9-10). ${ }^{10}$

Job's pious and steadfast trust in God - no matter what! - is almost comical (or tragicomical) given that God has not been faithful to him, but has handed him over to Satan as part of a wager. Job is faithful to God, but - unbeknownst to him - God is not faithful to him. The notion of a God who is faithless to the faithful is horrifying.

Nonetheless, Job does make some important theological statements in the framework story. Thus, he says: 'Naked came I out of my mother's womb and naked shall I return thither: the Lord gave and the Lord hath taken away; blessed be the name of the Lord' (Job 1:21). And when his wife, astonished by her husband's piety in the face of tragedy, tells him to blaspheme God and die, he replies: 'Shall we receive good at the hand of God, and shall we not receive evil?' (Job 2:10). Job thus argues that the service of God is for its own sake, and not for any ulterior motive. It is an end, not a means. Religion is not about bribing God, but serving Him. One must serve God, whether God hands one good or evil. This is a noble religious sentiment. The service of God should be disinterested - in good times and bad.

Job's theology in the Prologue may be compared with Lou Andreas-Salomé's Prayer to Life: 'If you have no more happiness to give me, | well then - give me your pain!' ('Hast du kein Glück mehr übrig mir zu geben, | wohlan so gieb mir deine Pein!'). ${ }^{11}$ Andreas-Salomé's prayer to Life echoes Job's prayer to God - one embraces both the joy and the suffering. Her prayer is Joban in its acceptance of pain, but Nietzschean in its requesting it.

However, how does Job's steadfast faith in God jibe with God's facile wager with Satan? Is this God worthy of Job's remarkable faith?

In the Epilogue, God tries to make amends to Job. He gives him twice as much wealth as he had before his afflictions, and He gives him seven ${ }^{12}$ new sons in place of the seven who had died, and three new daughters in place of the three who had died. Ten new children! In all the land, there were no women as beautiful as Job's new daughters (Job 42:15). Were they more beautiful than the first set? Perhaps. Nonetheless, no matter how wonderful the ten new children were, the original ten children are stone dead - and Job's new blessings do not change that. God had Job's first ten children killed. Do these ten new children somehow atone for the evil God did to Job? Does it make sense to say that God needs to make atonement? ${ }^{13}$ These are some of the questions that the framework story forces upon us.

If I ask myself why some ancient editor or redactor added the framework story to the book, I can think of two reasons: one heuristic and one pietistic. The heuristic reason is to help make a difficult book more accessible to the common reader. If the arguments in the body of the book are abstruse and challenging, the framework story is written in a popular style and provides an easy entry into the book. The pietistic reason is to help make a sometimes irreverent book more acceptable to pious readers. If in the body of the book Job brashly incriminates God (e.g. Job 9:22-24), in the framework story he is portrayed as a pious man who refuses to blaspheme Him (Job 1:22; $: 10$ ), and this piety redounds to his credit even when he later utters shocking words.

\section{God vs Job (Job 13:15-24)}

In chapter 13, Job reaffirms his unconditional but sober trust in God: 'Though He slay me, yet will I trust in Him' (Job 13:15; cf. 35:14). ${ }^{14}$ There is no Kierkegaardian paradox in Job's words here. He is simply reaffirming his faith in God - a faith independent of any reward. Note that Job's confrontation with God here is explicitly personal: though He slay me, yet 
will I trust in Him. Similarly, Job turns to God personally, and asks: 'Why dost Thou hide Thy face, and count me as Thy enemy' (Job 13:24). It's personal. God is the enemy of Job.

The irrational or arbitrary nature of God's behaviour towards Job is underscored by a comment on Job 9:17 found in the Babylonian Talmud, Baba Batra 16a. Job is portrayed as addressing God: 'Master of the Universe, perchance a stormy wind passed before You and caused You to confuse iyyob (Job) and oyeb (enemy)', which are anagrams in Hebrew. Is Job's suffering the result of an accidental smudge on God's parchment or an unfortuitous shift of the sand in His abax?

What gives Job the empowerment to argue so candidly with God? Job himself explains: 'This, moreover, shall be my salvation, that a hypocrite [hanef] cannot come before Him' (Job 13:16; cf. 8:13). Rashi (1040-1105), in his Commentary on Job, interprets Job's explanation as follows: God favours those individuals who 'are wholehearted with Him', but rejects those, like Eliphaz, Bildad, and Zophar, who seek to flatter Him (cf. Job 42:7). ${ }^{15}$ Malbim (1809-1879), in his Commentary on Job, paraphrases Job's words thus: 'God does not want to be flattered with words of falsehood . . . and does not want me to be silent and not speak the truth and the just.' Job is empowered to speak boldly and honestly with God because he knows God is the God of Truth. ${ }^{16}$

In affirming that a hypocrite cannot come before God, Job alludes with irony to the words of Bildad, who had railed against him: 'the hope of the hypocrite [hanef] shall be destroyed' (Job 8:13). Job believes in the possibility of his being heard by God precisely because he accepts Bildad's premise: a hypocrite cannot come before God.

\section{The Human Condition (Job I4:I-22)}

Suddenly in chapter 14 the argument shifts dramatically from the personal to the universal. Job had broached the problem of the lot of the human being in chapter 7, when he parodied Psalms 8:5 (cf. 144:3), asking: 'What is the human being that Thou makest such a big deal of him? [tegaddelennu]' (Job 7:17; cf. 7:1-2, 18). However, it is in chapter 14 that Job begins to speak earnestly about adam - the human being. He addresses the human condition. God is not only the enemy of Job, but the enemy of all human beings. Philosophy replaces biography. Job argues:

[1] A human being [adam] born of a woman is of few days and full of trouble.

[2] He cometh forth like a flower and withereth; he fleeth like a shadow and continueth not.

[3] And dost Thou open Thine eyes upon such a one, and bringest him ${ }^{17}$ into judgment with Thee?

The human being is so tiny, feeble, flimsy, transient, and insignificant. How can You, $\mathrm{O}$ mighty God, ask such a frail creature to stand in judgment before You. It's unfair! It's absurd!

With cold irony, Job argues that the lot of the human being is worse than that of the tree:

[7] For there is hope for a tree, if it be cut down, that it will sprout again . . .

[8] Though its root wax old in the earth and its stump die in the ground;

[9] Yet through the scent of water it will bud and put forth boughs like a young plant.

[10] But the human being dieth and is laid low: he breatheth his last, and where is he? ...

[12] The human being lieth down and riseth not again; till the heavens be no more, he will not awake nor be roused out of his sleep. 
The human being is not only feeble, frail, and transient, but he is without hope. The tree is cut down, but is rejuvenated; the human being dies, and remains dead forever. The tree is resurrected; the human being is not. The tree has hope; the human being has only despair. 'The life of man', wrote Hobbes, is 'solitary, poor, nasty, brutish, and short'. ${ }^{18}$ Human life, cries Job, is without hope. Job's theology is stark and unillusioned. Today, theologians, influenced by Jürgen Moltmann and others, speak sanguinely about 'a theology of hope'. The Book of Job - or at least certain chapters in it - presents a theology of hopelessness:

[19] The waters wear away the stones, the torrents wash away the soil of the earth; so Thou destroyest the hope of the human being [ve-tiqvat enosh he'ebadta] [cf. Job 8:13].

[20] Thou prevailest forever against him, and he passeth ...

Job accuses God: The hopelessness of the human condition is not accidental but part of Nature. As the waters wear away the stones, so God destroys human hope. Mighty God is an unfair match for the feeble human being. By necessity, God prevails against him, and he is lost. It is no contest. Because of the impossible odds, the infinite against the finite, the human being has no hope.

Does Job's accusation that God destroys human hope constitute a blaspheming of God, or does it somehow coexist with his disinterested faith in Him? If we are to take God's words literally when He says that His servant Job 'has spoken what is right' (Job 42:7), it seems we must say that Job's accusation is not blasphemy - but true religion.

Job's dictum that God 'destroyeth the hope of the human being' is his second direct allusion to Bildad's statement that 'the hope of the hypocrite shall be destroyed' (Job 8:13). At Job 13:16, Job had alluded to Bildad's statement and had argued that 'a hypocrite cannot come before [God]'. Here at 14:19, he alludes to Bildad's statement, but argues that God destroys not only hypocrites - but all human beings.

\section{God's Answer to Job out of the Whirlwind (Job 38:I-40:2)}

In chapter 38 , God answers Job out of the whirlwind:

[1] Then the Lord answered Job out of the whirlwind and said:

[2] Who is this that darkeneth counsel by words without knowledge?

[3] Gird up now thy loins like a man [ke-geber]; for I will question thee, and thou shalt declare unto Me.

[4] Where wast thou when I laid the foundations of the earth? Declare, if thou hast the understanding.

[5] Who determined its measurements, if thou knowest? .. .

[6-7] Who set its cornerstone, when the morning stars sang together, and all the sons of God shouted for joy?

[8] Who shut up the sea with doors? ...

[12] Hast thou commanded the morning? . . .

[31] Canst thou bind the chains of the Pleiades or loose the bands of Orion? ...

[35] Canst thou send forth lightnings? ...

[39] Wilt thou hunt the prey for the lioness? ...

[41] Who provideth for the raven his prey, when his young ones cry unto God?

After hearing Job's complaint, God replies to him with a series of questions, and challenges him sardonically to respond like a man. Did you lay the foundations of the 
earth? Have you created the sea? Did you place the stars in the sky? Do you provide for the needs of the lionesses and the raven? If you did not create the universe, you cannot understand it, and all your complaints are 'words without knowledge'. God concludes His reply to Job with another question: 'Shall a faultfinder contend with the Almighty? He who argueth with God, let him answer it' (Job 40:1-2). God's reply to Job exemplifies the ad hominem argument in its most powerful form. Who is the human being to contend with God? If you didn't create Space and Time, how can you argue with their Creator? But surely God knows as well as us that the ad hominem argument is a logical fallacy.

\section{Job's Reply to God (Job 40:3-5)}

In chapter 40, Job responds to God's ad hominem argument:

[4] Behold, I am of small account; what shall I answer Thee? I will lay my hand upon my mouth. ... .

[5] Once have I spoken once, and I will not answer again; yea, twice, but I will proceed no further.

Job has no reply, except to acknowledge the force of God's ad hominem argument ('I am of small account'), but then to remind God boldly of his previous remarks ('I have spoken once ... twice'), which he will in no way retract. ${ }^{19}$ Job's silence expresses his staunch defiance. $^{20}$

In point of fact, God's argument is precisely Job's - mutatis mutandis. Job had argued that it is unfair for God to judge human beings, since God is almighty and human beings are tiny and feeble. For His part, God argues that it is impossible for human beings to judge God, since God is almighty and human beings are tiny and feeble. Both God and Job argue that the incomparability of God and human beings makes dialogue impossible. What is to be learned from God's greatness and the human being's insignificance? That we should be silent, or that God should be silent?

\section{God Questions Job Further (Job 40:6-41:26)}

Following Job's laconic reply, God once again presses him with questions, and once again taunts him to respond like a man. In the continuation of chapter 40, God addresses Job:

[7] Gird up now thy loins like a man [ke-geber]. . . .

[8] Wilt thou reject My judgment [mishpat]? Wilt thou condemn Me that thou mayest be justified?

[9] Hast thou an arm like God? Canst thou thunder with a voice like His? . . .

[15] Behold now Behemoth! ... .

[24] Shall anyone capture him? ...

[25] Canst thou draw out Leviathan with a fishhook or press down his tongue with a cord? ...

[28] Will he make a covenant with thee?

There is no moral ground between the infinite and sublime God and the finite and crass human being. Since there is no possibility of moral discourse, Job has no basis to contest God's judgment. The works of the Creator of Behemoth and Leviathan are inscrutable and incontrovertible.

It is not clear if God's judgment is incontestable because human beings lack the relevant knowledge to evaluate it, or if it is incontestable because the categories of human 
morality simply do not apply to it. In other words, is God's judgment ultimately moral but difficult to comprehend, or is it amoral ${ }^{21}$ In any case, the God described in God's own words to Job is a God of awe - a mighty, wondrous, fearsome God.

It cannot be denied, however, that God's awe-inspiring speeches lose some of their power when seen against the background of the framework story. There God is not the almighty Creator of Leviathan and Behemoth, but the celestial potentate who makes irresponsible bets with Satan.

\section{A God of Love?}

The Hebrew Bible often speaks about God as a God who loves human beings (e.g. Deuteronomy 7:8; 9:15; 10:18; Jeremiah 31:2; Zephaniah 3:17; Proverbs 3:12). However, is the God portrayed in the Book of Job a God of love?

In the Talmud, it is said that God sometimes causes the righteous to suffer in order to benefit them in some way. Such sufferings are called 'sufferings of love' (BT Berakhot 5a; cf. Proverbs 3:12). The sufferings of the righteous individual are thus an expression of God's love for him or her. The Talmud does not explicitly apply this concept to Job's sufferings. However, medieval authors, like Levi Gersonides and Simeon ben Semah Duran, did explicitly apply it to him. ${ }^{22}$

The notion that Job's sufferings reflect God's love is found in medieval Christian authors like Augustine ${ }^{23}$ and Aquinas, ${ }^{24}$ and in the contemporary Thomist philosopher Eleonore Stump. Stump understands the book to be about God's 'goodness' and 'providence'. Job, she argues, comes to know in the end that 'God loves him and did not betray his trust'. ${ }^{25}$

Such interpretations by Augustine, Aquinas, Gersonides, Duran, Stump, and others are theologically resourceful and often inspiring, but do not answer to the simple reading of the text. According to the simple reading of the text, God does betray the trust of Job by allowing Satan to harm him. As Job puts it: 'God hath subverted my cause' (19:6; see 9:19 and 31). As for love, God never says that he loves Job and Job never says that God loves him. Job's God is a sublime and mighty God, but not a God of agápē. The only 'love' mentioned in the Book of Job is unrequited and tragic (Job 19:19).

\section{Zelda's Question}

The Book of Job portrays vividly the distance between God and the human being. This distance is mostly conceived as cognitive: the great God is unable to understand the tiny human being, and the tiny human being is unable to understand the great God.

In her poem 'Al Tirhaq ('Be Not Far'), the Hebrew poet Zelda reinterprets this distance in a different way. The problem, as her poem presents it, is not that the distant God may not be able to understand Job, but that He may not be able to have compassion for him. ${ }^{26}$ Here is the final stanza of her poem:

Creator of nights and wind, is not this terrible weeping before You, be not far -

let not millions of light years

stand as a barrier

between You and Job. ${ }^{27}$

Zelda's worry is that the distant God will not hear Job's terrible weeping. Her poem ignores God's awesomeness and focuses on His possible lack of compassion. 


\section{Conclusion}

The Book of Job is a powerful and tormenting work that raises fundamental existential questions about God and humanity, good and evil, and the human condition. It gives no dogmatic answers. However, it invites us to confront the Problem of Evil, and to explore the cruel but sublime asymmetrical relationship between God and human beings. As for its framework story, it compromises the profound thoughts advanced in the speeches found in the body of the book, but also serves to make a difficult and at times shocking text more accessible to the common reader and more acceptable to the pietist. While it does not try to resolve the Problem of Evil, the Book of Job provides an honest basis for its philosophic discussion.

\section{Notes}

1. This article is a revised version of a talk given to instructors in the Literature Humanities course at Columbia College, November 2013. I thank Professor Christia Mercer for inviting me to give the talk, and Dr Bakinaz Abdalla for encouraging me to revise it for Religious Studies. Quotations from the Book of Job will be given in the 1917 Jewish Publication Society translation, but sometimes modified.

2. Sacks (1999), 80. Cf. P. Weiss (1969), 181-182: the Book of Job is 'one of the very great works of literature' and 'probes to the root of the problems of good and evil, ... the wisdom and goodness of God, and the justification of suffering', but its Prologue depicts a 'childishly conceived God' and a 'childlike God'. Although the Prologue is written in a naïve style, it is crafted with consummate skill; see M. Weiss (1983).

3. Ibn Ezra (2020) remarks in his Commentary on Job 2:11: 'it seems likely to me that it is a translated book; thus, it is difficult to interpret like every translated book'. See Viezel (2017), 113-157.

4. Spinoza (1925), 110-111, 144. See Harvey (2010), 42.

5. See Greenfield (1980), xiv-xvi.

6. Maimonides (1963), 486-497. Cf. Gersonides (1946), xvii-xix. See Eisen (2004).

7. See Greenstein (2019), 134:

Elihu . . . is neither introduced [at Job 2:11] nor mentioned at the end [at Job 42:7-9] . . These facts, together with subtle differences in language and style . . . lead most modern scholars to regard [the Elihu chapters] as a later addition . . . The motive for [the addition] . . . is apparent. The divine discourses dwell on God's power and majesty . . . Elihu . . . adds the dimensions of divine concern for humanity and morality [e.g. Job 34:10-20].

Regarding the opinion of the medieval Jewish philosophers, see Eisen (2004), 209: 'One of the more surprising features of the interpretations of Job [by the medieval Jewish philosophers] examined in this study is their unanimous position that it is Elihu who provides Job with the correct explanation for his suffering.'

8. Maimonides (1963), III, 23, 494-495:

If someone considers [Elihu's] discourse, he ... thinks that he does not ... make an addition to what was said by Eliphaz, Bildad, and Zophar ... [This misdirection] is in order to hide [the differences of opinion] so that at first it occurs to the multitude that all the interlocutors are agreed, but this is not so.

See Weber (2015).

9. Maimonides (1963), III, 22, 487: 'The most marvelous and extraordinary thing about this story is the fact that knowledge is not attributed in it to Job. He is not said to be wise or . . . intelligent. Only moral virtue and righteousness in action are ascribed to him.'

10. Job 2:9 is sometimes included among the more than eighteen problematic biblical texts that, according to the Rabbis, were emended by the Members of the Great Assembly. Three of these verses are found in the Book of Job. At Job 2:9, 'curse [qallel] God' was changed to 'bless [barekh] God'; at 7:20, 'I am a burden to Thee ['alekha]' was changed to 'I am a burden to myself ['alai]'; and at 32:3, 'they condemned the Lord [adonai]' was changed to 'they condemned Job [iyyob ]'. See, for example, Ginsberg (2021).

11. Andreas-Salomé (2013), 47. Cf. Nietzsche (1908), Zar1, 88. See Schwab (2017).

12. See Job 42:13, shib'anah. This unusual Hebrew word is understood by some as being an archaic dual form meaning 'fourteen'. The text would accordingly be speaking of fourteen new sons. In the Aramaic Targum, the number fourteen is given explicitly. However, Job 42:13-14 testifies that he had only three new daughters. 
13. See Kaufmann (1969), 241: '[T]he book does not say ... that [the conclusion] vindicates God's mercy or justice, or that Job felt that his second set of ten children was fair compensation for the first ... [The conclusion] underlines the weirdness of the ways of the world, which is nothing less than grotesque.'

14. The Masoretic text gives two readings here: a ketib ('the written text') and a qeri ('the read text'): the former is $l_{0}$ ' ayahel ('I do not trust') and the latter lo ayahel ('I trust in Him'). Citing these two readings, the French Jewish existentialist, André Neher, wrote of the paradoxical 'faith of qeri-ketib'. See Neher (1981), 197: 'Job says two words [viz., lo and $l 0^{\circ}$ ] . . . simultaneously denoting hope and despair. . . "I do not hope" [and] "I hope in Him," these simultaneous but contradictory cries being the matrix of a new world.'

15. Cf. Gersonides (1946), 99.

16. Cf. Maimonides (1963), II, 47, 409: 'for only Truth pleases Him . . . and only the false angers Him'.

17. The Masoretic text reads here 'me' (oti), but the context requires 'him' (oto). The latter reading is found in the Septuagint (sou) and the Peshitta (we-leh).

18. Hobbes (1971), Leviathan, I, 13, 186. Hobbes is speaking about the 'time of war', not the 'time of peace'. However, Job speaks about the human condition in every time. Hobbes not only borrows the title of Leviathan from the Book of Job (40:25-41:26; esp. 40:28; cf. 3:8), but cites the book significantly. See Hull (2002).

19. See Matitiahu Tsevat (1966), 76: 'Job's backbone is not broken. Up to the last verses of the book, he ... stands upright ... [and] grows in strength.'

20. Not all readers agree that Job remains defiant. Some think his silence reflects a recanting or repenting. Verbin (2010), 139, believes Job 'forgives' God. Readers who hold that Job recanted, repented, or forgave usually cite Job 42:6, but this verse bears diverse interpretations. For example, Maimonides (1963), III, 23, 493, 497, translates: 'I repent of my being in dust and ashes', that is, I regret my excessive mourning. See Kaplan (1978), 356-358. 21. See Tsevat (1966), 102, 105:

The laws of the natural order and ... the moral order are not of a piece. If you decide to do what is good, do it because it is good [and not out of hope for reward or fear of punishment] ... The Book of Job does more than demythologize the world; it ... 'demoralizes' it ... makes it amoral ... He Who speaks to [the human being] in the Book of Job is neither a just nor an unjust god but God.

On the similar interpretations of Job by Iris Murdoch and Yeshayahu Leibowitz, see Harvey (2018), 616-617. Cf. Morriston (1996): 'Could the author of the divine speeches [in the Book of Job] . . . be intentionally undermining . . . ethical monotheism?'

22. Eisen (2004), 146, 183-184.

23. Augustine (1913), II, xii (17), 89; xvi (25), 98: 'We know [from Job 1:8] that it was not due to his sins, but for the sake of demonstrating his righteousness that he had to endure all those [tribulations] ... "Whom He loves, he corrects [quem diligit corripit]" [Proverbs 3:12].' See Ticciati (2013), 270: '[T] he voice with which God speaks out of the whirlwind [job 38:1-42:6] [is] one of power ... [and] cannot straightforwardly be equated with gracious love. But it is a connection Augustine himself makes.' Both a biblical scholar and a theologian, Ticciati trenchantly concludes that the Augustinian reading of Job is non-literal and anachronistic, but 'at the deepest level awak[ens] new meaning in the book of Job' (p. 271).

24. Aquinas (1965), ch. $37(=36)$, on $36: 33$ : 'He declareth [the light] to His friend $\left[r^{e} e_{0}=a m i c o s u o\right]$ ', that is, 'the virtuous person whom God loves [virtuoso quem Deus amat]'.

25. Stump (2010), 225-226.

26. The word 'compassion' (rahamim) in its various forms appears more than 100 times in the Hebrew Bible, but not once in the Book of Job (although the word rehem [= womb] appears four times). However, the word does appear in a discussion of Job in the Qur'ān. See Sürah 21 (The Prophets):83-84, where Job in his affliction calls out to God: 'Thou art the Most Compassionate of the Compassionate [arham al-rāhimin]'; and God, in response, removes his affliction.

27. Alter (2015). The poem is cited here in Alter's translation (p. 181). Cf. Zelda (1974), 89.

\section{References}

Alter R (2015) Hebrew poems rewriting Job. In Batnitzky L and Pardes I (eds), The Book of Job: Aesthetics, Ethics,

Hermeneutics. Berlin: De Gruyter, pp. 173-184.

Andreas-Salomé L (2013) Lebensrückblick: Autobiographie. Hamburg: Severus Verlag, p. 47.

Aquinas T (1965) Expositio super Iob ad litteram. Rome: Leonine Commission.

Augustine of Hippo (1913) De peccatorum meritis et remissione. Vienna: Tempsky; Leipzig: Freytag.

Eisen R (2004) The Book of Job in Medieval Jewish Philosophy. Oxford: Oxford University Press.

Gersonides L (1946) Commentary on the Book of Job, tr. Lassen AL. New York: Bloch. 
Ginsberg J (2021) 'New Tiqqunei Soferim', Taylor-Schechter Genizah Research Unit, Cambridge University Library, Fragment of the Month: July 2021. Available at https://www.lib.cam.ac.uk/collections/departments/taylorschechter-genizah-research-unit/fragment-month/fotm-2021/fragment-5.

Greenfield JC (1980) Introduction. In The Book of Job: A New Translation According to the Traditional Hebrew Text, with introductions by Greenberg M, Greenfield JC and Sarna NM. Philadelphia, PA: Jewish Publication Society, pp. xiv-xvi. Greenstein EL (2019) Job: A New Translation. New Haven: Yale University Press.

Harvey WZ (2010) Spinoza on Ibn Ezra's Secret of the Twelve. In Melamed YY and Rosenthal MA (eds), Spinoza's Theological-Political Treatise: A Critical Guide. Cambridge: Cambridge University Press, pp. 41-55.

Harvey WZ (2018) Hannah Kasher on Leibowitz (in Hebrew). In Elqayam A and Malachi A (eds), Minhah le-Hannah: Jubilee Book in Honor of Hannah Kasher. Tel-Aviv: Idra, pp. 611-620.

Hobbes T (1971) Leviathan, ed. Macpherson CB. New York: Penguin Books.

Hull G (2002) Against this Empusa: Hobbes's Leviathan and the Book of Job. British Journal for the History of Philosophy 10, 3-29.

Ibn Ezra A. (2020) Commentary on Job (in Hebrew). In Cohen M (ed.), Miqra’ot Gedolot: Ha-Keter. Ramat-Gan: Bar-Ilan University Press.

Kaplan L (1978) Maimonides, Dale Patrick, and Job 42:6. Vetus Testamentum 28, 356-358.

Kaufmann W (1969) An uncanny world. In Glatzer NN (ed.), The Dimensions of Job. New York: Schocken, pp. 237-245.

Maimonides M (1963) The Guide of the Perplexed, tr. Pines S. Chicago: University of Chicago Press.

Malbim = Rabbi Meir Leibush ben Jehiel Michael Weiser (1879) Commentary on Job (in Hebrew). Warsaw: Eisenstadt.

Morriston W (1996) God's answer to Job. Religious Studies 31, 339-356. Reproduced in Abdalla B (ed.), Topics in Jewish Philosophy of Religion (=Religious Studies Archives 2), 2021. Available at https://www.cambridge.org/ core/journals/religious-studies/article/abs/gods-answer-to-job/5203FBC98C3A7BE388F08F82D70195A0.

Neher A (1981) The Exile of the Word, tr. Maisel D. Philadelphia, PA: Jewish Publication Society.

Nietzsche F (1908) Ecce Homo. Leipzig: Insel.

Rashi = Rabbi Solomon Isaaci (2020) Commentary on Job (in Hebrew). In Cohen M (ed.), Migra'ot Gedolot: Ha-Keter. Ramat-Gan: Bar-Ilan University Press.

Sacks RD (1999) The Book of Job with Commentary. Atlanta: Scholars Press.

Schwab H-R (2017) Zu meinem Gedächtnis: Nietzsche und Lou Andreas-Salomés Gebet an das Leben. In Benne C and Zittel C (eds), Nietzsche und die Lyrik. Stuttgart: Metzler, pp. 479-491.

Spinoza B (1925) Tractatus Theologico-Politicus. In Gebhardt C (ed.), Opera. Heidelberg: Carl Winter, vol. 3, pp. 110-111, 144.

Stump E (2010) Wandering in Darkness. Oxford: Oxford University Press.

Ticciati S (2013) An intertextual reading of Job in relation to the anti-Pelagian Augustine. In Dell KJ and Kynes W (eds), Reading Job Intertextually. London: Bloomsbury, pp. 259-271.

Tsevat M (1966) The meaning of the Book of Job. Hebrew Union College Annual 37, 76.

Verbin N (2010) Divinely Abused: A Philosophical Perspective on Job and his Kin. New York: Continuum.

Viezel E (2017) Ibn Ezra's Commentary on Job 2:11. Hebrew Union College Annual 88, 113-157.

Weber GC (2015) Maimonides and the Epicurean position on providence. Review of Metaphysics 68, 545-572.

Weiss M (1983) The Story of Job's Beginning. Jerusalem: Magnes.

Weiss P (1969) God, Job, and Evil. In Glatzer NN (ed.) The Dimensions of Job. New York: Schocken, pp. 181-193.

Zelda (1974) Al Tirhaq. Tel-Aviv: Hakibbutz Hameuchad.

Cite this article: Harvey WZ (2022). Questions on the Book of Job. Religious Studies 1-10. https://doi.org/10.1017/ S0034412521000585 